\title{
Hafif Blok Üretiminde Çanakkale Ayvacık Volkanik Tüfünün Agrega Olarak Kullanılabilirliğinin Araştırılması
}

\section{Investigation of the usability as an aggragate in the production of lightweight block of Çanakkale-Ayvacık Volcanic Tuff}

\section{Seyide Kılıçaltan ${ }^{1}$, Ŭgur Demir ${ }^{2 *}$}

${ }^{1}$ Dumlupınar Üniversitesi, Maden Mühendisliği Bölümü, Kütahya, Orcid No: 0000-0001-7878-0068

${ }^{2}$ Dumlupınar Üniversitesi, Maden Mühendisliği Bölümü, Kütahya, Orcid No: 0000-0001-8828-4711

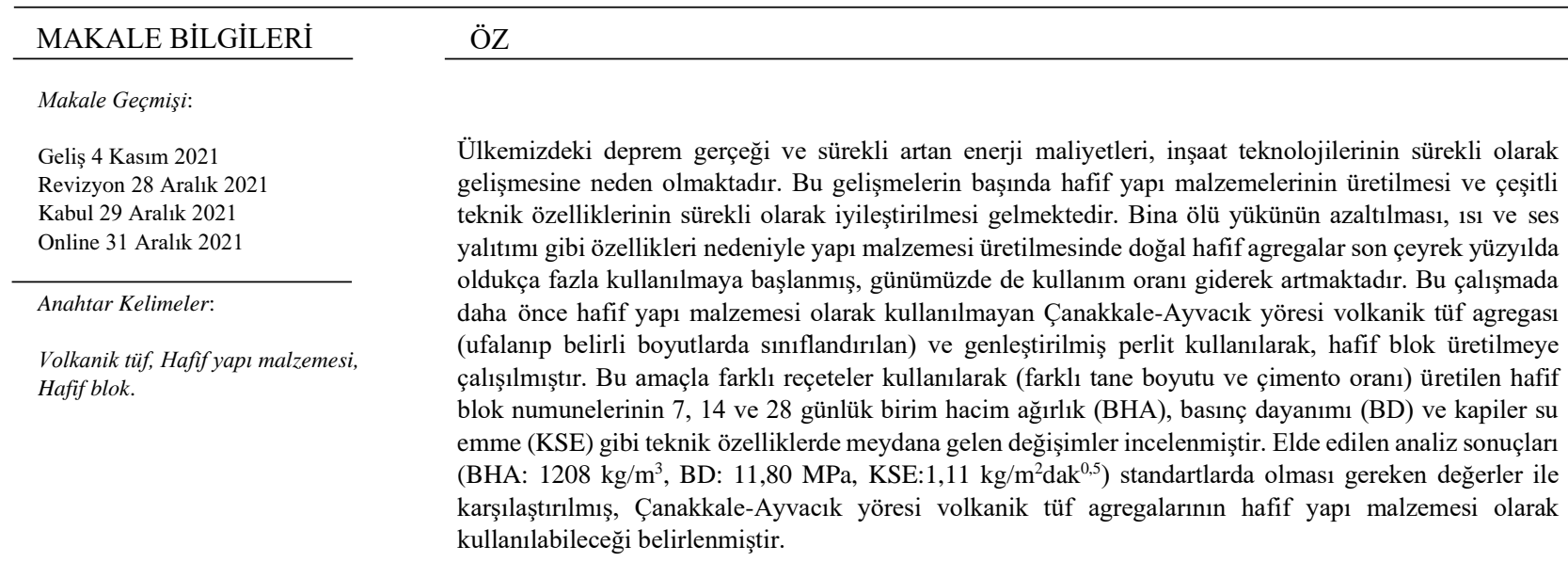

\begin{tabular}{|c|c|}
\hline ARTICLE INFO & ABSTRACT \\
\hline Article history: & \\
\hline $\begin{array}{l}\text { Received } 4 \text { November } 2021 \\
\text { Received in revised form } 28 \\
\text { December } 2021 \\
\text { Accepted } 29 \text { December } 2021 \\
\text { Available online } 31 \text { December } 2021 \\
\text { Keywords: } \\
\text { Volcanic tuff, Lightweight builging } \\
\text { materials, lightweight block }\end{array}$ & $\begin{array}{l}\text { The fact of earthquakes in our country and the ever-increasing energy costs cause the continuous } \\
\text { development of construction technologies. At the beginning of these developments is the production of } \\
\text { lightweight building materials and the continuous improvement of their various technical properties. Due } \\
\text { to its features such as reducing the dead load of the building, heat and sound insulation, natural lightweight } \\
\text { aggregates have been used quite a lot in the last quarter century, and today the usage rate is increasing } \\
\text { gradually. In this study, light blocks were tried to be produced by using volcanic tuff aggregate (crushed } \\
\text { and classified) from Canakkale-Ayvacik region, which was not used as a lightweight building material } \\
\text { before. For this purpose, changes in technical properties such as unit volume weight (BHA), compressive } \\
\text { strength (BD) and capillary water absorption (KSE) of light block samples produced using different recipes } \\
\text { were investigated during the curing periods of } 7,14 \text { and } 28 \text { days. The analysis results (BHA: } 1208 \mathrm{~kg} / \mathrm{m}^{3} \text {, } \\
\text { BD: } 11,80 \mathrm{MPa} \text {, KSE: } 1,11 \mathrm{~kg} / \mathrm{m}^{2} \mathrm{dak}^{0,5} \text { ) obtained were compared with the values that should be in the } \\
\text { standards, and it was determined that the volcanic tuff aggregates from Çanakkale-Ayvactk region could } \\
\text { be used as light construction material. }\end{array}$ \\
\hline
\end{tabular}

Doi: 10.24012/dumf. 1051469 be used as light construction material.

* Sorumlu Yazar 


\section{Giriş}

Deprem yükünü azaltması, hem ses hem de 1sı yalıtımında üstün özelliklerinin bulunması, yangına karşı direnç, estetik özellikleri, enerji maliyetlerindeki artış ve yasal düzenlemelerin yalıtımı zorunlu hale getirmesini hafif yapı malzemelerinin inşaat sektöründe yaygın olarak kullanılmasının sebepleri olarak sıralayabiliriz [1],[2]. Hafif yapı malzemeleri, binanın ölü yükünü azaltmasından dolayı, bina hafiflemekte (daha güvenli hale gelmekte), binanın taşıyıcı sistem elemanlarının kesitlerinde meydana gelen küçülme ise maliyetlerin önemli oranda azalmasına neden olmaktadır [3]-[8]. Yüksek isıl performansa ve mekanik dayanıma sahip olan hafif yapı malzemeleri hem enerji verimliliğini sağlarken hem de daha az yakıt kullanılması nedeniyle çevrenin daha az kirlenmesine neden olmaktadır [9]. Hafif yap1 malzemesi üretiminde volkanik tüf [4], volkanik cüruf [10],[11], pomza [4]-[8],[10],[12]-[16], diyatomit [1],[13], vermikulit, ignimbirit [16],[17], perlit ve genleştirilmiş perlit [2],[9],[18], genleştirilmiş kil [10],[17] gibi doğal ve genleştirilmiş polistiren sert köpük (EPS) gibi sentetik [2],[9],[19] malzemeler de kullanılmaktadır. Hafif yapı malzemelerinin birim hacim ağırlıklarının 2000 $\mathrm{kg} / \mathrm{m}^{3}$ 'den küçük olması gerekmektedir [6],[13]. Kaliteli hafif agregalarda su emme oranının $\% 15$ 'in altında olması ve basınç dayanımının ise en az $5 \mathrm{MPa}$ olması gerekmektedir [20].

Volkanik tüf, volkanik püskürme boyunca kraterden dışarı çıkan, konsolide olmuş volkankülü veya volkan tozundan oluşan kayaçlardır. Volkanik tüf, bazı kül ve mineral parçalarının yanmış ve kavrulmuş halde havaya fırladığı ve yüzeye düşüp karışarak depolandığı zaman oluşmaktadır [4],[21]. Volkanik tüfler genellikle çok düşük birim hacim ağırlı̆̆ına, çok yüksek poroziteye ve çok fazla şekil değiştirme yeteneğine sahiptir. Tüf ortalama $1300{ }^{\circ} \mathrm{C}$ 'de erimekte, $760{ }^{\circ} C^{\prime}$ 'nin altında herhangi bir değişime uğramamaktadır. Doğal nem oranı düşük, sertliği 5,5-6 arasında, basınç mukavemeti ise $95-130 \mathrm{~kg} / \mathrm{m}^{2}$ arasındadır [4]. Tüfler, genelde pembe ve beyaz olarak ayrilabilmekte, beyaz tüfler genellikle tüflü yapının içine gömülmüş küçük metamorfik kayaç parçaları olan fenokristaller iken pembe tüflerde ise çoğunlukla tüflü yapının içine gömülmüş büyük metamorfik parçalar olan fenokristllerden oluşurlar [21]. Tüf agregalarının ana bileşeni $\mathrm{SiO}_{2}$ 'dir, $\mathrm{Si}$ ile birlikte $\mathrm{Al}_{2} \mathrm{O}_{3}$ varlığındaki artış puzolanik aktiviteyi ve dolayısıyla basınç dayanımının artışına neden olmaktadır [4].

Çeşitli doğal ve sentetik agregalar ile hafif yapı malzemesi üretilmesine yönelik yapılmış çalışmalar ve elde edilen sonuçlar aşağıda özetlenmiştir.

[4]'de Afyonkarahisar tüfü ve Isparta pomzasını kullanarak 4 farklı kalıpta hafif beton üretilmesine yönelik çalışma yapmış, aynı zamanda farklı çimento miktarlarında elde edilen ürünlerin basınç dayanımı, birim hacim ağırlık ve ısıl iletkenlik özelliklerini standartlarda belirtilen testleri uygulayarak belirlemişdir. [10]'da Isparta-Karakaya, IspartaGelincik, Kayseri, Nevşehir pomzası ile Kula volkanik cürufu ve genleştirilmiş kil numuneleri kullanılarak hafif yap1 malzemesi üretilmeye çalışılmıştır. Elde edilen ürünlerin çeşitli teknik özellikleri standartlarda belirtilen testler uygulanarak belirlenmeye çalışılmış, en düşük birim hacim ağırlığın Kayseri pomzası ile en yüksek birim hacim ağırlığın
Kula volkanik cürufu ile elde edildiği tespit edilmiştir. [11]'de hafif beton üretmek amaciyla Elazı̆̆-Yeniköy volkanik cürufunu tek başına ve kum ile belirli oranlarda karıştırarak kullanılmış, elde edilen ürünün ısıl iletkenlik ve basınç dayanım özelliklerini belirlemek amacıyla standartlarda belirtilen testler uygulamıştır. Test sonuçları elde edilen ürünlerin hafif yapı malzemesi olduğunu göstermiştir.

[12]'de farklı yörelerden elde edilen (Nevşehir-Göre, Kayseri-Talas, İzmir-Menderes) pomza agregalarından hafif yapı malzemesi üretmeye çalışmış, bu üç yöre malzemelerini farklı kombinasyonlarda karıştırarak elde ettikleri ürünlerin teknik özellikleri incelemişdir. Ürünlerin teknik özelliklerinin oluşum şartları ile de ilişkili oldukları belirlenmişdir. [14]'de hafif beton üretmek amaciyla doğal Nevşehir pomza agregası ile sentetik EPS kullanılmış, elde ettikleri hafif betonun 1sı iletkenlik, basınç dayanımı ve ses yutuculuk gibi teknik özellikleri incelenmiştir. Elde edilen sonuçlar pomza ve EPS kullanılarak hafif beton üretilebileceğini göstermiştir. Araştırmacılar yaptıkları bu çalışmada, büyük kalıplar kullanarak elde ettikleri ürünleri, istedikleri ebatlarda daire testere ile kesebildiklerini belirtmişlerdir. [5]'de hafif beton üretmek amacıyla Isparta-Gölcük pomzası ile çimentoya farklı oranlarda silis dumanı ilave edilmiş, elde edilen ürünlerin birim hacim ağırlık, basınç dayanımı ve ultrases geçiş hızları standartlarda belirtilen testler uygulanarak belirlenmiştir. Artan silis dumanı miktarı teknik özelliklerde pozitif etkiler gösterdiği tespit edilmiştir. [15]'de Isparta yöresi pomzası kullanarak hafif bölme panel duvar üretmeye çalışılmış, bu amaçla farklı oranlarda çimento ve katkı maddesinin basınç dayanımı üzerine etkilerini incelenmişdir. Çimento ve katkı oranı arttıkça elde edilen ürünün basınç dayanımında belirgin artışlar elde edilirken, birim hacim ağırlıkta ise belirgin artışların olduğu tespit edilmiştir. [6]'da Isparta, Kayseri, Nevşehir ve Karaman yöresi pomza agregalarını hafif yapı malzemesi üretmek amacıyla kullanılmış, elde edilen ürünlerin standartlarda belirtilen basınç dayanımı, 1sı iletkenliği, ses yututuculuğu ve ses iletimi gibi özellikleri farklı ebatlarda üretilen beton numuneleri üzerinde test edilmiştir. Teknik özelliklerin pomza oluşum şartlarından etkilendiği belirlenmiştir. [7]'de Tekirdağ-Çorlu kumu ile Kayseri-Talas pomzasını farklı oranlarda karıştırarak hafif beton üretilmiş, elde edilen ürünün yangın etkisi sonrasında çeşitli teknik özelliklerde meydana gelen değişimler incelenmiştir. Pomza miktarının artışı yangına karşı dayanımda belirgin artışlara neden olurken, beton yüzeyinde oluşan sıcaklıkta da belirgin azalışların oluştuğunu belirtilmiştir. [8]'de Van-ErçişKocapınar pomza agregası kullanarak hafif yapı malzemesi üretilmesine yönelik çalışmada, farklı kür uygulamalarının elde edilen malzemelerde su emme ve 1sı iletkenliği üzerine etkileri incelenmişdir. 28 gün boyunca günde 3 kere yapılan sulama işlemi sonucunda elde edilen ürünlerin su emme oranında belirgin bir azalma meydana gelirken, 1s1l iletkenlikte az da olsa bir iyileşmenin olduğu tespit edilmiştir.

[1]'de hafif beton üretmek amaciyla Afyonkarahisar diyatomit numuneleri kullanılmış, farklı çimento oranlarının elde edilen ürünlerin birim hacim ağırlık, basınç dayanımı ve 1sıl iletkenlik özelliklerinde meydana gelen değişimler incelenmişdir. Çimento miktarındaki artışın basınç dayanımında olumlu yönde etki ettiği, birim hacim ağırlıkta 
ise olumsuz yönde etki ettiği belirlenmişdir. [13]'de hafif ve yarı hafif beton üretmek amaciyla Isparta-Atabey agregası, Gölcük pomzası ve Keçiborlu diyatomitlerini belirli oranlara karıştırılmış ve elde edilen ürünlerin teknik özelliklerinin standartlarda belirtilen sınır değerleri karşılayıp karşılamadıkları tespit edilmiştir.

[17]'de hafif yap1 malzemesi üretmek için Aksaray ignimbiriti kullanılmış, farklı tane boyutlarındaki agrega ile farklı çimento oranları kullanarak, elde edilen ürünlerin standartlarda belirtilen değerleri karşılayıp karşılamadıkları tespit edilmiştir. [16]'da Nevşehir pomzasını tek başına ve ignimbirit ile belirli oranlarda karıştırarak hafif yapı malzemesi üretilmiş, elde edilen ürünlerin birim hacim ağırlık ve basınç dayanımlarında meydana gelen değişim incelenmiştir. Pomza agregasına ignimbirit ilavesi ile basınç dayanımında önemli oranda iyileşme meydana gelirken, birim hacim ağırlıkta belirgin bir artışın olduğu belirlenmiştir.

[18]'de hafif beton üretiminde hafif agrega olan perlit ve genleştirilmiş perliti ayrı ayrı kullanılmış ve elde edilen ürünlerin birim hacim ağırlık, su emme ve basınç dayanım özelliklerindeki değişimler incelenmişdir. Genleştirilmiş perlit kullanımı birim hacim ağırlıkta önemli oranda azalamaların olmasına neden olurken, hem su emme hem de basınç dayanımında negatif etkilerinin olduğu belirlenmiştir. [2]'de hafif yapı malzemesi üretmek amaciyla İzmir Etimaden tarafından üretilen genleştirilmiş perlit, sentetik CMC malzemesi ve kömür tozu kullanılmış, elde edilen ürünlerin standartlara uygunlukları çeşitli testler uygulanarak belirlenmiştir. [9]'da hafif yapı malzemesi elde etmek için doğal agrega olan pomza ve genleştirilmiş perlit ile birlikte lastik parçaları kullanılmış, elde edilen ürünlerin çeşitli teknik özellikleri standartlarda belirtilen testler kullanarak belirlemeye çalışılmışdır. Yazarlar aynı zamanda ürünlerin teknik özelliklerini yapay sinir ağları tekniğini kullanarak tahmin edilebileceğini belirlenmişlerdir.

[3]'de hafif taşıyıcı yapı malzemesi üretmek amacıyla farklı çimento oranlarında Alman kökenli genleştirilmiş kil ve kum belirli oranlarda karıştırılarak kullanılmış, elde edilen ürünün taşıyıcı özelliklilerinin belirlenmesi amacıyla standartlarda belirtilen testler uygulanmıştır. Elde edilen ürünlerin taşıyıcı özellikte olduğu belirlenmişdir.

[19]'da hafif alçı blok üretmek amacıyla Sivas yöresi jibs numunesi, sentetk EPS malzemesi ve pomza agregasını farklı kombinasyonlarda karıştırılarak kullanılmıştır. Elde edilen ürünlerin kuru yoğunluk, basınç dayanım, su emme ve isıl iletkenli özelliklerin standart test yöntemleri kullanarak belirlenmişdir.

$\mathrm{Bu}$ çalışmada, üzerinde pek çalışma yapılmamış olan Çanakkale Ayvacık Akçin yöresi doğal volkanik tüf agregasının hafif yapı malzemesi (hafif blok) olarak kullanılabilirliği araştırılmıştır. $\mathrm{Bu}$ amaçla farklı boyut gruplarındaki (0-2 mm ve 2-4 mm) agregalar farklı oranlarda kullanılmış, bununla beraber farklı çimento oranlarının (\%2838) Birim Hacim Ağırlık (BHA), Kapiler Su Emme (KSE) ve Basınç Dayanımlarındaki (BD) etkileri incelenmiş, elde edilen ürünlerin standartları karşılayıp karşılamadığı irdelenmiştir.

\section{Malzeme ve Yöntem}

\section{Malzeme}

Deneysel çalışmalarda kullanılan volkanik tüf agregası Çanakkale iline bağlı Ayvacık ilçesinin yaklaşık 13 km kuzey-doğusunda bulunan Akçin köyü yakınlarında aktif olarak çalışan özel bir firmaya ait ocaktan alınmıştır. Doğal agregaların alındığı sahanın yer bulduru haritası Şekil 1'de verilmiştir.

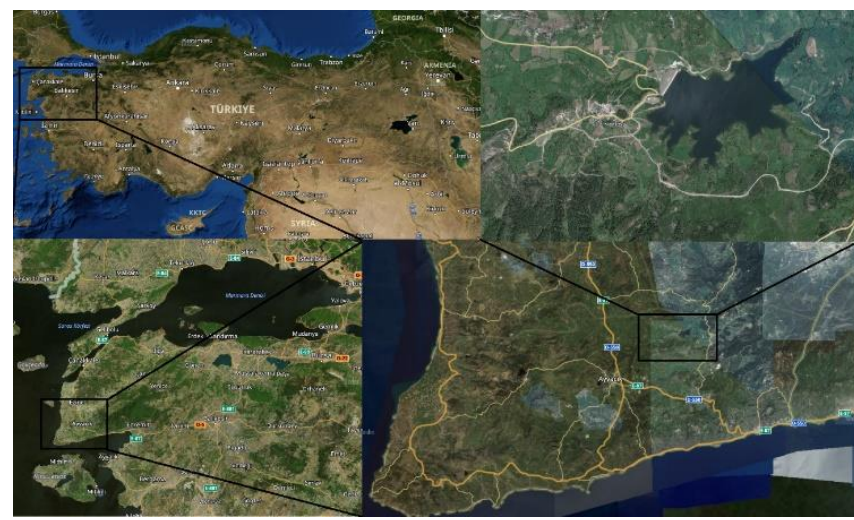

Şekil 1. Yer bulduru haritası (googlemap)

Alınan temsili numunelerin tüvenan, boyutu küçültüldükten ve boyut gruplarına ayrıldıktan (0-2 mm ve 2-4 mm) sonraki halleri ile genleştirilmiş perlit numunesi Şekil 2'de verilmiştir. Ocaktan alınan numuneler Kütahya Dumlupınar Üniversitesi Maden Mühendisliği Laboratuvarına getirilmiş, çeneli kırıcı yardımı ile ufalanan agrega numunesi boyut dağılımının belirlenmesi amacıyla elek analizine tabi tutulmuştur. Elek analiz sonuçları Şekil 3'de, kimyasal analiz sonuçları ise Tablo 1'de verilmiştir.

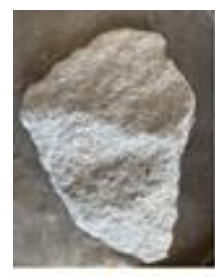

a

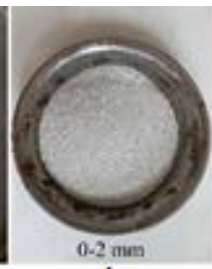

b

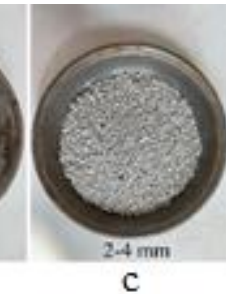

C

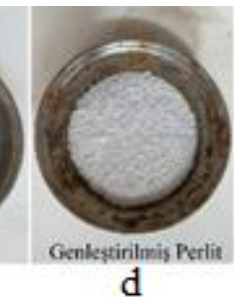

d
Şekil 2. a-Parça, b-0-2 mm, c-2-4 mm volkanik tüf ve dgenleştirilmiş perlit görüntüleri

Tablo 1. Çalışmada kullanılan numunelerin kimyasal analiz sonuçları

\begin{tabular}{cc}
\hline İçerik & $\%$ \\
\hline $\mathrm{SiO}_{2}$ & 65,22 \\
$\mathrm{Al}_{2} \mathrm{O}_{3}$ & 16,03 \\
$\mathrm{TiO}_{2}$ & 0,22 \\
$\mathrm{Fe}_{2} \mathrm{O}_{3}$ & 1,75 \\
$\mathrm{CaO}$ & 1,8 \\
$\mathrm{MgO}$ & 2,7 \\
$\mathrm{Na} 2$ & 1,97 \\
$\mathrm{~K}_{2} \mathrm{O}$ & 3,4 \\
$\mathrm{~K} . \mathrm{K}$ & 6,43 \\
\hline
\end{tabular}




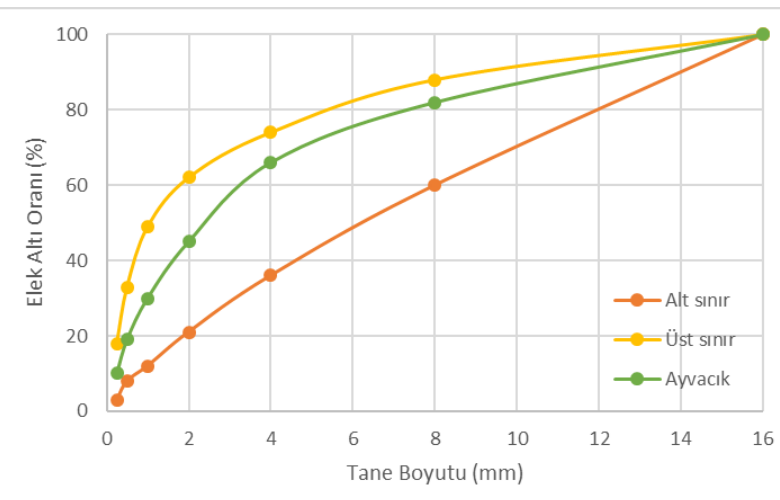

Şekil 3. Ufalama işleminden sonraki gronülometrik dağılım

Ufalama işlemi sonucu elde edilen ürünün gronülometrik dağılımı Şekil 3'de verilmiştir (TS 1114). Hafif blok üretmek amaciyla doğal agrega $0-2$ ve $2-4 \mathrm{~mm}$ boyut gruplarına ayrılmıştır. Tablo 2'de ufalama işleminden sonra elde edilen numunelerin $0-2$ ve $2-4 \mathrm{~mm}$ boyut aralığındaki miktarları ve özgül ağırlıkları verilmiştir. Hafif blok üretim aşamasında Gen-Per firmasından temin edilen genleştirilmiş perlit \%1 seviyelerinde kullanılmıştır.

Tablo 2. 0-2 ve 2-4 mm agrega özgül ağırlıkları

\begin{tabular}{cc}
\hline Tane boyutu $(\mathrm{mm})$ & Özgül Ağırlık $\left(\mathrm{kg} / \mathrm{m}^{3}\right)$ \\
\hline Tüf Agregası $(0-2 \mathrm{~mm})$ & 756 \\
Tüf Agregası $(2-4 \mathrm{~mm})$ & 1197 \\
\hline
\end{tabular}

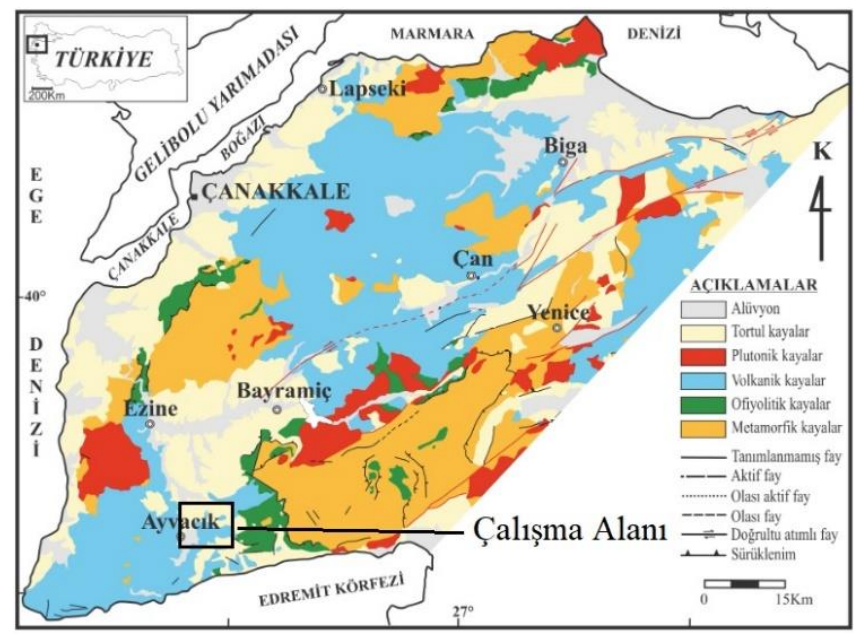

Şekil 4. Biga Yarımadası'nda gözlenen ana kaya grupları ve çalışma alanı [22]

Şekil 4'de Biga Yarımadası'nda gözlenen ana kaya grupları ve çalışma alanı görülmektedir. Biga yarımadası, KD-GB yönlü tektonik unsurları barındıran bir yapıya sahiptir. Yarımadanın temelini Geç Karbonifer-Erken Triyas yaşlı Kazdağ Metamorfitleri oluşturmaktadır. $\mathrm{Bu}$ kayaçların üzerinde tektonik olarak yerleşmiş arkozik kumtaşları, grovaklar, bazaltik kayaçlar, tüfler, aglomeralar ve kireçtaşlarından oluşan Geç Permiyen-Erken-Orta Triyas yaşlı Karakaya Kompleksi ve metamorfizma geçirmiş epiklastik-piroklastik kökenli litolojilerden ve bunları kesen metagranodiyoritlerden oluşan Triyas yaşlı Kalabak Birimine ait kayaçlar bulunmaktadır. Geç Kretase'de ofiyolitik kayaçlardan oluşan bir melanj gelmiştir. Bölgede Tersiyer,
Orta Eosen neritik kireçtaşları ve bunların üzerine uyumlu olarak gelen volkanik ara katkılı Geç Eosen türbiditleriyle başlar. Oligossen sonunda Biga Yarımadasında önemli bir yükselme ve aşınma evresi olmış ve yarımadanın güneyindeki Orta Eosen-Oligosen istifi tümüyle aşınmıştır. Bölgede Erken-Orta Miyosen'de volkanik kayaçlarla eş yaşlı bitümlü şeyl, silttaşı, kumtaşı, tüf ve kömürden oluşan tortullar meydana gelmiştir. Oligosen-Miyosen döneminde kalkalkalen magmatizma bölgeyi etkilemiş, ayrıca andezit, dasit, riyolit ve asidik tüfler geniş alanlara yayılmıştır. Biga Yarımadasında volkanizmaya bağlı olarak Geç OligasenErken Miyosen aralığında oluşmuş, genellikle granodiyoritik bileşimli sı̆̆ sokulumarın varlığı bilinmektedir. Tersiyer'de gerilme tektoniğiyle şekillenen havzalarda genellikle karasal tortullar yoğun bir volkanizma eşliğinde oluşmuştur. Geç Miyosen volkanizması sonlanırken, fluviyal klastikler Biga Yarımadasının kuzeyinde çökelmiştir. Pliyo-Kuvaterner'de Biga Yarımadasında çakıltaşı, kumtaşı ve şeyl bileşimli fluviyal çökeller ile gölsel karbonatlar oluşmuş ve az miktarda alkali bazaltik volkanizma meydana gelmiştir [22].

Deneysel çalışmalarda hafif blok üretiminde ÇimSa markalı Cem II 42,5 R beyaz çimento kullanılmıştır. Kullanılan çimentonun kimyasal bileşimi Tablo 3 'de ve çeşitli özellikleri Tablo 4'de verilmiştir.

Tablo 3. Deneysel çalışmalarda kullanılan çimentonun kimyasal bileşimi

\begin{tabular}{cc}
\hline Bileşenler & Değerler (\%) \\
\hline $\mathrm{CaO}$ & $60-67$ \\
$\mathrm{SiO}_{2}$ & $17-25$ \\
$\mathrm{Al}_{2} \mathrm{O}_{3}$ & $3-8$ \\
$\mathrm{Fe}_{2} \mathrm{O}_{3}$ & $0,5-6,0$ \\
$\mathrm{MgO}$ & $0,1-0,4$ \\
$\mathrm{Na}_{2} \mathrm{O}+\mathrm{K}_{2} \mathrm{O}$ & $0,2-1,3$ \\
$\mathrm{SO}_{3}$ & $1,0-3,0$ \\
$\mathrm{~K}_{1}$ 1zdırma Kayb1 & $1,0-2,0$ \\
Çözünmeyen Kalıntı & $1,0-2,0$ \\
\hline
\end{tabular}

Tablo 4. Deneysel çalışmalarda kullanılan çimentonun çeşitli özellikleri (TS EN 197-1 CEM II 42.5R)

\begin{tabular}{cc}
\hline Özellikler & Değerler \\
\hline $\mathrm{SO}_{3}$ & 3.15 \\
Çözünmeyen Kalıntı (\%) & 0.66 \\
Kızdırma Kaybı(\%) & 2.05 \\
Priz Başlangıcı(dak.) & 150 \\
İncelik (cm²/g) & 3450 \\
2 Günlük Basınç Dayanımı $(\mathrm{MPa})$ & 25 \\
28 Günlük Basınç Dayanımı $(\mathrm{MPa})$ & 48 \\
\hline
\end{tabular}

Hafif blok üretilmesi sırasında agrega ve çimentonun istenilen etkileşimi göstermesi için Kütahya Dumlupınar Üniversitesi Evliya Çelebi Yerleşkesi çeşme suyu kullanılmıştır. Çimento-su karışım oranı oldukça önemli bir durumdur, aynı oranda önemli olan bir diğer durum ise tane boyut dağılımıdır. Karışıma fazla su ilave edilmesi, numunelerin şekil almasında sorunlara neden olurken, çökme 
olarak tarif edilen durumun olmasina da neden olabilmektedir.

Elde edilen karışımların Birim Hacim Ağırlık (BHA), Basınç Dayanımı ve Kapiler Su Emme özelliklerinin standartlarda (TS EN 1015-10, TS EN 1015-11 ve TS EN 1015-18) belirtildiği şekilde test edilebilmesi için $5 \times 5 \times 5 \mathrm{~cm}$ ve 10x10x10 cm'lik ahşap kalıplar kullanılmıştır.

\section{Yöntem}

Hafif Blok elde etmek amaciyla $0-2$ ve 2-4 mm boyutlarındaki agregalar ağırlıkça $\% 60$ ve $\% 40$ oranlarında karıştırılmıştır. \%1 oranında genleştirilmiş perlit ilave edilmiştir. 2 farklı seri oluşturulacak şekilde karıştırılmıştır. 1 seride \%60 0-2 mm agrega ile \%40 2-4 mm agrega, 2 seride \%40 0-2 mm agrega ile \%60 2-4 mm agrega karıştırılmıştır (Tablo 5 ve 6). Karışımlarda \%28-38 oranında çimento ilave edilerek 6 farklı reçete hazırlanmıştır.

Tablo 5. Hafif blok 1. Seri karışım oranları

\begin{tabular}{ccccccc}
\hline & 1.1 & 1.2 & 1.3 & 1.4 & 1.5 & 1.6 \\
\hline Bileşenler & \multicolumn{7}{c}{ Ağırlık (\%) } \\
0-2mm \%60 & 42,6 & 41,4 & 40,2 & 39 & 37,8 & 36,6 \\
2-4mm \%40 & 28,4 & 27,6 & 26,8 & 26 & 25,2 & 24,4 \\
P. ÇìMENTO & 28 & 30 & 32 & 34 & 36 & 38 \\
G. Perlit & 1 & 1 & 1 & 1 & 1 & 1 \\
Toplam & 100 & 100 & 100 & 100 & 100 & 100 \\
\hline
\end{tabular}

Tablo 6. Hafif beton 2. Seri karışım oranları

\begin{tabular}{ccccccc}
\hline & 2.1 & 2.2 & 2.3 & 2.4 & 2.5 & 2.6 \\
\hline Bileşenler & \multicolumn{7}{c}{ Ağırlık (\%) } \\
0-2mm \%40 & 42,6 & 41,4 & 40,2 & 39 & 37,8 & 36,6 \\
2-4mm \%60 & 28,4 & 27,6 & 26,8 & 26 & 25,2 & 24,4 \\
P. ÇİMENTO & 28 & 30 & 32 & 34 & 36 & 38 \\
G. Perlit & 1 & 1 & 1 & 1 & 1 & 1 \\
Toplam & 100 & 100 & 100 & 100 & 100 & 100 \\
\hline
\end{tabular}

Hafif blok numunelerinde hesaplamalar sonucu su-çimento oranı belirlenerek farklı karışımlar elde edilmiş, $5 \times 5 \times 5 \mathrm{~cm}$ ve 10x10x10 cm ebatlarındaki kalıplara dökülmüş kalıp yüzeyleri mala ile düzeltilmiştir. Numunelerin yapışmaması için yağlanan kalıplarda 24 saat bekletilen numuneler, dikkatli bir şekilde çıkartılmıştır (Şekil 3). Kalıplardan çıkarılan numuneler 7, 14 ve 21 günlük kür süreleri için laboratuvar koşullarında oda sıcaklığında bekletilmiştir. Elde edilen hafif betonların birim hacim ağırlık [23] (TS EN 101510), kapiler su emme [24] (TS EN 1015-18) ve basınç dayanım testleri [25] (TS EN 1015-11) ilgili standartlara uygun olarak gerçekleştirilmiştir. Her bir test için 4 adet numune kullanılmış ve elde edilen sonuçların ortalamaları alınmıştır.

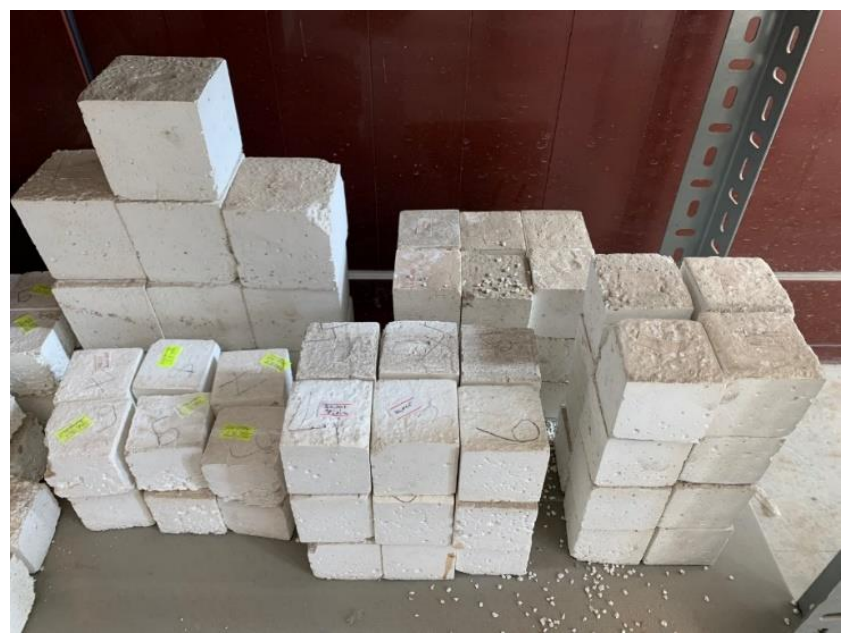

Şekil 5. Farklı tane boyutu ve çimento miktarlarında üretilen hafif blok numuneleri

\section{Sonuçlar}

\section{Birim Hacim Ağırlık}

Farklı tane boyutu ve çimento oranlarında karıştırılarak elde edilen hafif blok numunelerinin SBB 1 ve SBB 2 seri için 7 , 14 ve 21 günlük kür süresinden sonra oluşan birim hacim değerleri Şekil 6 ve 7'de verilmiştir.

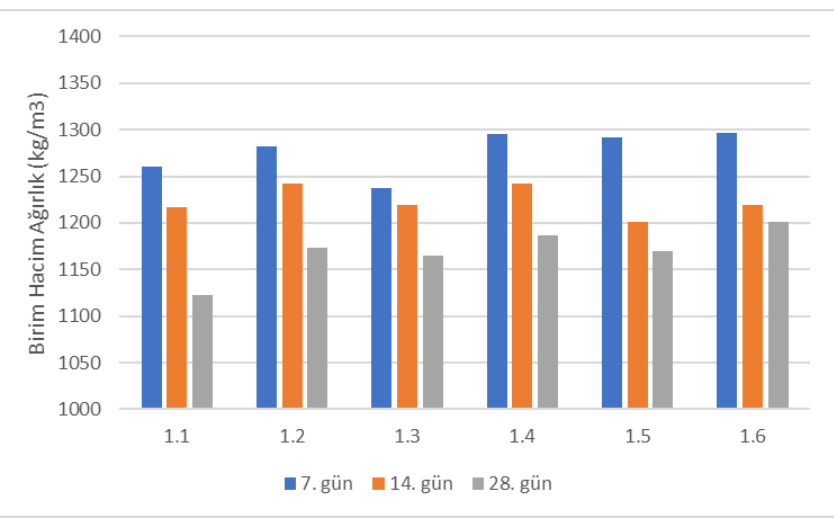

Şekil 6. Hafif blok 1. Seri karışımlarından elde edilen numunelerin BHA değişimi

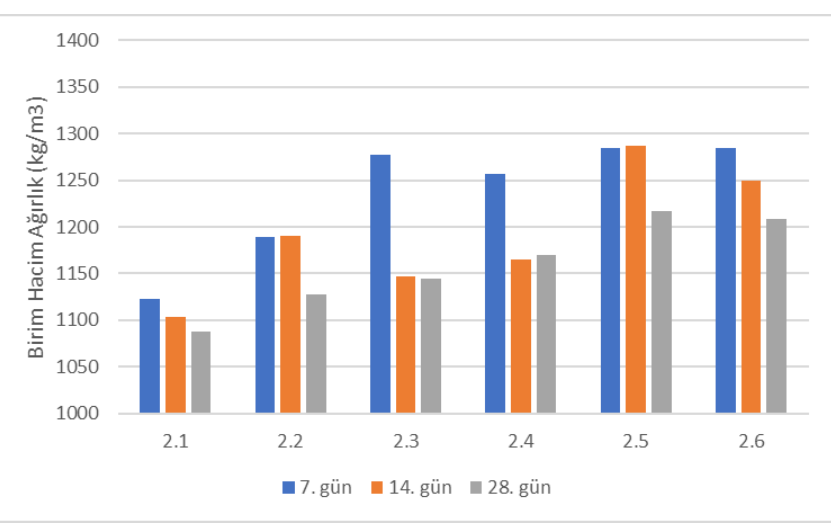

Şekil 7. Hafif blok 2. Seri karışımlarından elde edilen numunelerin BHA değişimi

Hafif blok elemanlarının BHA değerlendirmesi, blok elemanlarının etüv kuru durumunda bürüt kuru birim ağırlık ve net kuru birim hacim ağırlık olarak tanımlanmaktadır. Hafif blok numunelerine TS EN 1015-10 standardına uygun 
olarak BHA testleri uygulanmıştır. Artan çimento miktarı elde edilen hafif blokların BHA değerlerinde düzenli bir artışın olmadığ 1 , belirli oranlarda dalgalanmaların olduğu belirlenmiştir. 1 serisinde kullanılan $0-2 \mathrm{~mm}$ tane boyutundaki malzeme miktarı daha fazla olması, BHA değerlerinin 2 serisine göre daha yüksek olduğu görülmektedir. 1 serisinde kür süresi arttıkça tüm çimento oranlarında BHA'da belirgin bir azalma söz konusudur. Çimento oranı artışına bağlı olarak 1 serisinde sadece \%32 çimento oranında tüm kür sürelerinde BHA değerlerinde belirgin bir azalma gözlemlenirken, diğer çimento oranlarında düzenli bir değişim meydana geldiğ görülmüştür. 7 günlük kür süresinde BHA değerleri 1260 $1296 \mathrm{~kg} / \mathrm{m}^{3}$ arasında iken 14 günlük kür süresinde 1217-1219 $\mathrm{kg} / \mathrm{m}^{3}, 28$ günlük kür süresinde $1122-1201 \mathrm{~kg} / \mathrm{m}^{3}$ değerleri arasında kaldığı, çimento oranı artışı BHA değerlerinde sınırl seviyelerde artışa neden olmuştur. 2 serisinde kullanılan 2-4 $\mathrm{mm}$ iri boyutlu malzeme miktarı BHA değerlerinde göreceli olarak daha düşük değerlerin elde edilmesine neden olmuştur. 7 günlük kür süresinde $1120-1284 \mathrm{~kg} / \mathrm{m}^{3}, 14$ günlük kür süresinde $1103-1249 \mathrm{~kg} / \mathrm{m}^{3}, 28$ günlük kür süresinde ise $1088-1208 \mathrm{~kg} / \mathrm{m}^{3}$ arasında değerler elde edilmiştir.

Hafif blok numunelerinin BHA değerleri karşılaştırıldığında hafif yapı malzemesi için gerekli olan $<2000 \mathrm{~kg} / \mathrm{m}^{3}$ değerinden oldukça düşük BHA'lar elde edilmiştir. Hafif blok numunelerine ilave edilen genleştirilmiş perlit BHA değerlerinde belirgin bir azalmanın meydana gelmesine neden olmuştur.

\section{Basınç Dayanım}

Farklı tane boyutu ve çimento oranlarında karıştırılarak elde edilen hafif blok numunelerinin 1 ve 2 serileri için 7, 14 ve 21 günlük kür süresinden sonra oluşan basınç dayanım değerleri Şekil 8 ve 9'da verilmiştir.

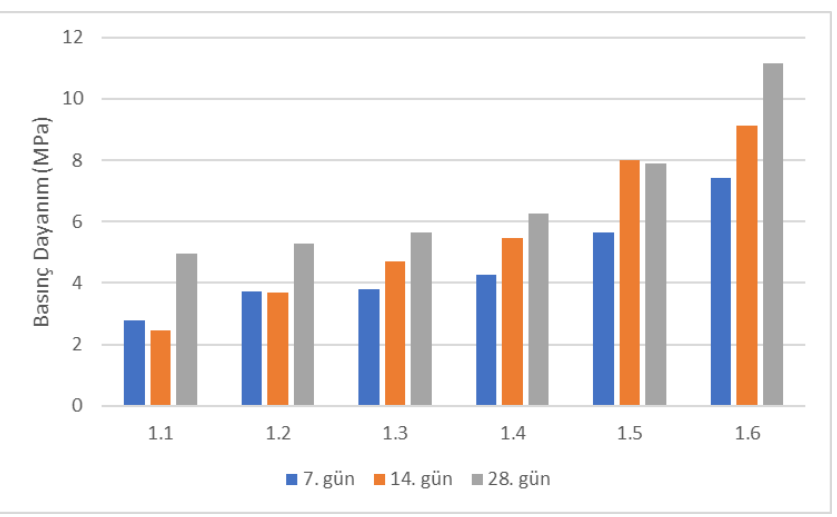

Şekil 8. Hafif blok 1. Seri karışımlarından elde edilen numunelerin basınç dayanım değişimi

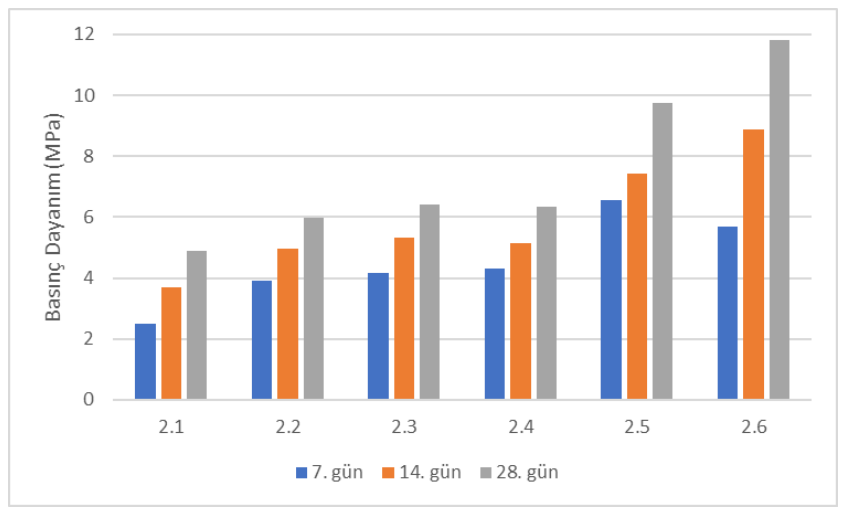

Şekil 9. Hafif blok 2. Seri karışımlarından elde edilen numunelerin basınç dayanım değişimi

Hafif blok üretiminde hem çimento miktarındaki artış hem de kür süresindeki artış, basınç dayanım değerlerinden düzenli bir artışın meydana gelmesine neden olmuştur. Hafif blok üretiminde kullanılan hafif agregaların artan çimento miktarına göre değişiminde ilave edilen genleştirilmiş perlit, basınç dayanımları üzerinde önemli etkiler ortaya çıkarmaktadır. Genleştirilmiş perlit ilavesi BHA değerlerinde olumlu etkiler gösterirken, basınç dayanım değerlerinin belirgin bir şekilde azalmasına neden olmaktadır. 1 serisinde 7 günlük kür süresinde 2,79-7,43 $\mathrm{MPa}, 14$ günlük kür süresinde 2,47-9,11 $\mathrm{MPa}$ ve 28 günlük kür süresinde 4,96$11,16 \mathrm{MPa}$ arasında basınç dayanım değerleri elde edilmiştir. 2 serisinde 7 günlük kür süresinde 2,48-5,67 MPa, 14 günlük kür süresinde 3,71-8,86 MPa ve 14 günlük kür süresinde 4,9$11,80 \mathrm{MPa}$ aralığında basınç dayanım değerleri elde edilmiştir. İnce taneli agrega miktarının 1 serisinde daha fazla olmasına rağmen elde edilen basınç dayanımlarında da belirgin azalma olması dikkat çekicidir, bu durumun genleştirilmiş perlitten kaynaklandığg düşünülmektedir.

\section{Kapiler Su Emme}

Yapı malzemelerinin içine giren su, yapı malzemesinin nem ile birlikte 1sı dengesinin de bozulmasına, büzülme ve şişme gibi hacimsel deformasyonlara neden olmaktadır. Oluşan bu deformasyonlar zamanla malzeme bünyesinde mikro çatlakların oluşmasına akabinde ise bu çatlaklardan daha fazla suyun girerek hareket etmesine neden olmaktadır. Yap1 malzemesi içerisine doğrudan veya dolaylı olarak giren su, yapılarda hasarlara, küflenmeye ve yüzey bozulmalarına neden olmaktadır [26]. Son olarak farklı tane boyutu ve çimento oranlarında karıştırılarak elde edilen hafif blok numunelerinin 1 ve 2 serileri için kapiler su emme değerleri ilgili standartta belirtildiği (TS EN 1015-18) gibi sadece 28 günlük kür süresinde bekletilmiş numunelere yapılmış ve elde edilen sonuçlar Tablo 7 ve 8'de verilmiştir.

Tablo 7. 1 serisi hafif blok numunelerinin kapiler su emme test sonuçları

\begin{tabular}{cc}
\hline Numune No & $\begin{array}{c}\text { Kapiler Su Emme } \\
\mathrm{kg} /\left(\mathrm{m}^{2} . \mathrm{dak}^{0.5}\right)\end{array}$ \\
\hline 1.1 & 0,99 \\
1.2 & 1,08 \\
1.3 & 1,02 \\
1.4 & 1,12 \\
1.5 & 1,15 \\
1.6 & 1,19 \\
\hline
\end{tabular}


Tablo 8. 2 serisi hafif blok numunelerinin kapiler su emme test sonuçları

\begin{tabular}{cc}
\hline Numune No & $\begin{array}{c}\text { Kapiler Su Emme } \\
\mathrm{kg} /\left(\mathrm{m}^{2} . \mathrm{dak}^{0.5}\right)\end{array}$ \\
\hline 2.1 & 0,98 \\
2.2 & 0,98 \\
2.3 & 1,17 \\
2.4 & 1,12 \\
2.5 & 1,03 \\
2.6 & 1,11 \\
\hline
\end{tabular}

Hafif blok numunelerinin artan çimento miktarına bağlı olarak kapiler su emme değerleri incelendiğinde, çimento miktarındaki artış çok azda olsa kapiler su emme değerlerinde bir artışın olduğu gözlemlenmiştir. $\mathrm{Bu}$ durum hafif blok üretilmesi sırasında kullanılan genleştirilmiş perlitin blok dış yüzeyi ile iç yüzeyi arasındaki bağlantının çok sınırlı seviyelerde kalmasından ileri gelmektedir.

\section{Tartışma}

Elde edilen sonuçlar toplu olarak değerlendirildiğinde hafif blok üretimden elde edilen en iyi sonuçlar Çizelge 9'da verilmiştir. Tablo 9 incelendiğinde artan çimento miktarı BHA değerlerinde sürekli olarak bir artışın meydana gelmesine neden olurken, basınç dayanım değerlerinde de belirgin bir artış elde edilmiştir. Literatürden farklı olarak artan çimento miktarında çok az da olsa su emme oranlarında bir artışın olduğu görülmüştür. Genleştirilmiş perlit elde edilen hafif blok numunelerinin özellikleri üzerinde belirgin bir etki ettiği görülmektedir.

Tablo 9. 2 seri hafif blok numunelerin 28 günlük kür süresindeki test sonuçları

\begin{tabular}{cccc}
\hline $\begin{array}{c}\text { Numune } \\
\text { No }\end{array}$ & $\begin{array}{c}28 \text {. Gün } \\
\text { BHA } \\
\left(\mathrm{kg} / \mathrm{m}^{3}\right)\end{array}$ & $\begin{array}{c}\text { 28. Gün Basıç } \\
\text { Dayanımı } \\
(\mathrm{MPa})\end{array}$ & $\begin{array}{c}\text { Kapiler Su } \\
\text { Emme } \\
\mathrm{kg} /\left(\mathrm{m}^{2} \cdot \mathrm{dak}^{0.5}\right)\end{array}$ \\
\hline 2.1 & 1088,04 & 4,90 & 0,98 \\
2.2 & 1127,78 & 5,98 & 0,98 \\
2.3 & 1144,15 & 6,40 & 1,17 \\
2.4 & 1169,3 & 6,34 & 1,12 \\
2.5 & 1217,11 & 9,34 & 1,03 \\
2.6 & 1208,58 & 11,80 & 1,11 \\
\hline
\end{tabular}

Hafif blok numunelerinin hafif yapı malzemesi olabilmesi için gerekli olan $2000 \mathrm{~kg} / \mathrm{m}^{3}$ birim hacim ağırlık değerinin çok altında değerler elde edilmiş, TS EN 13055 standardında belirtilen $1100 \mathrm{~kg} / \mathrm{m}^{3}$ değerine çok yakın değerler elde edildiği görülmektedir. Volkanik tüf numunelerinin sıkışma özelliğinin yüksek olması [4], ve genleştirilmiş perlit kullanımı bu sınır değerin üstüne çıkılma sebebi sayılabilir. Basınç dayanım değerleri standartlarda $>5 \mathrm{MPa}$ 'dan büyük olması gerektiği belirtilmektedir. Elde edilen ürünlerin basınç dayanım değerleri incelendiğinden sadece 1.1 numunesinin $5 \mathrm{MPa}$ dan daha düşük olduğu görülmektedir. Diğer tüm karışımlar standartlarda belirtilen değerleri karşılamaktadır. Son olarak üretilen hafif yap1 malzemelerinin kapiler su emme oranlarının oldukça düşük seviyelerde olduğu görülmektedir.
Tüm sonuçlar değerlendirildiğinde, Çanakkale-Ayvacık yöresine ait volkanik tüf agregası hafif yapı malzemesi olarak kullanılabileceği belirlenmiştir. Yöre hammaddeleri üzerinde daha geniş kapsamlı çalışmaların yapılması, yöre hammaddelerinin ülke ekonomisine kazandırılması açısında önem arz etmektedir. Bu çalışma Çanakkale-Ayvacık volkanik tüf agregasının hafif yapı malzemesi olarak kullanılabilirliğinin araştırıldığı ilk çalışma niteliğindedir. Başka araştırmacıların yöre ile ilgilenmesinin önünün açılması açısından da önemlidir.

"Hazırlanan makalede etik kurul izni alınmasına gerek yoktur"

"Hazırlanan makalede herhangi bir kişi/kurum ile çıkar çatışması bulunmamaktadır"

\section{Yazarların katkıları}

Kılıçaltan, Çalışma konsepti ve tasarım, Veri toplama

Demir, Çalışma konsepti ve tasarım, Verilerin analizi ve yorumlanması, Taslağın oluşturulması, Revizyon

\section{Kaynaklar}

[1] O. Ünal, T. Uygunoğlu, "Diyatomitin Hafif Beton Üretiminde Kullanılması” İMO Teknik Dergi, 4025 4034, Yaz1 266, 2007

[2] A. G. Çelik, A. M. Kılıç, F. Akkurt, "Yapı Malzemesi Üretiminde Genleştirilmiş Perlit Agregası Kullanılabilirliğinin Araştırılması" Gazi Üniv. Müh. Mim. Fak. Der. Cilt 29, No 3, 451-458, 2014

[3] S. Subaşı, “Genleştirilmiş Kil Agregası İle Taşıyıcı Hafif Beton Üretimi” Gazi Üniv. Müh. Mim. Fak. Der. Cilt 24, No 3, 559-567, 2009

[4] M. Kozak, O. Ünal, "Hafif Agregalı Blokların Özelliklerinin Araştırılması" Yapı Teknolojileri Elektronik Dergisi Cilt: 6, No: 2, 17-30, 2010,

[5] A. Beycioğlu, C. Başyiğit, Ş. Kılınçarslan, "Pomza Agregalı Hafif Beton Özelliklerine Silis Dumanının Etkisi” Süleyman Demirel Üniversitesi, Fen Bilimleri Enstitüsü Dergisi, 14-2,200-205, 2010

[6] Ş. Kılıçarslan, M. Davraz, M. Akça, "Pomza Agregalı Köpük Betonların Özelliklerinin Araştırılması" Mühendislik Bilimleri ve Tasarım Dergisi 6(1), 148 153,2018

[7] V. Akyüncü, "Pomza Agregalı Hafif Beton Blokların Mekanik Özeliklerinin Ve Yangın Etkisi Altındaki Davranışının İncelenmesi” Ömer Halisdemir Üniversitesi Mühendislik Bilimleri Dergisi, Cilt 8, Sayı 1, 147-157, 2019

[8] O. Geçten, R. Gül, "Hafif Ve Normal Agregalı Betonlarda Atmosferik Kürün Su Emme, Rötre Ve Isı İletkenliği Üzerine Etkileri” TÜBAV Bilim 12 (3), 2031,2019 , 
[9] Ş. Fidan, H. Oktay, S. Polat, "Hafif Yap1 Malzemelerinin Isıl İletkenlik Özelliklerinin Yapay Sinir Ağları Kullanılarak Tahmin Edilmesi” Batman Üniversitesi Yaşam Bilimleri Dergisi, Cilt 10, Sayı 1, 2020

[10] M. Davraz, E. Başpınar, “Agrega Porozitesinin Hafif Betonların Fiziko-Mekanik Özelliklerine Etkisi “ SDU International Technological Science, Vol. 3, No 3,pp 35-51, 2011

[11] A. Biçer, "Make Use of Volcanic Slag as Aggregate in the Production of Concrete" Uluslararas1 Doğu Anadolu Fen Mühendislik ve Tasarım Dergisi, 2(2), 337-347, 2020

[12] H. Ceylan, M. S. Saraç, "Farklı Pomza Agrega Türlerinden Elde Edilen Hafif Betonun Sicaklık Etkisindeki Bazı Özellikleri Üzerine Bir Araştırma" Süleyman Demirel Üniversitesi, Fen Bilimleri Enstitüsü Dergisi, 10-3,413-421, 2006,

[13] G. Serin, O. Çankıran, C. Başyiğit, H. H. Taş, M. Fenkli, "Normal, Hafif ve Yarı Hafif Beton Blokların Fiziksel ve Mekanik Özelliklerinin Karşılaştırılması" Yap1 Teknolojileri Elektronik Dergisi, (1) 15 - 22 2007,

[14] A. Sarışık, G. Sarışık, "Yeni Üretim Prosesi İle Pomza Agregalı Hafif Beton Ve Eps Köpüklü İzolasyon Blok Üretimi, Standartlara Uygunluğu Diğer Duvar Yapı Elemanları İle Karşılaştırılması" Madencilik, Cilt 49, Sayı 2, Sayfa 27-39, 2010,

[15] H. Tatlidil, E. Sancak, "Pomza Agregalı Hafif Betonların Panel Duvar Üretiminde Kullanılabilirliğinin Araştırılması" SDU International Technologic Science, Vol. 5, No 2, pp. 87-94, 2013

[16] A. Bilgil, H. Özdel, "Pomza Esaslı Ve İgnimbirit Katkılı Hafif Yapı Malzemesinin Fiziksel Ve Mekanik Özelliklerinin İncelenmesi” Ömer Halisdemir Üniversitesi Mühendislik Bilimleri Dergisi, Cilt 6, Sayı 2, 475-482, 2017,
[17] N. Şapçı, L. Gündüz, F. Yağmurlu, “Aksaray İgnimbritlerinin Doğal Hafif Agrega Olarak Kullanılabilirliği Ve Hafif Formda Boşluklu Duvar Blok Elemanlarının Üretiminde Değerlendirilmesi” Pamukkale Üniversitesi Mühendislik Bilimleri Dergisi, Cilt 20, Sayı 3, 2014, Sayfalar 63-69 2014

[18] H. S. Gökçe, O. Şimşek, G. Durmuş, İ. Demir, "Ham Perlit Agregalı Hafif Beton Özelliklerine Alternatif Genleştirilmiş Perlit Kullanımının Etkisi” Politeknik Dergisi, Cilt:13, Say1: 2, s. 159-163, 2010

[19] S. Şahin, S. Karaman, "The Properties of Expanded Polystyrene - Pumice - Gypsum Blocks as a Building Material" Journal of Tekirdag Agricultural Faculty , vol 9, (1), 2012

[20] C. Yolcu, Z. C. Girgin, "Dünyada Yapay Hafif Agregalı Yapısal Beton Uygulamaları Ve Doğal Pomza Agreganın Kullanılabilirliği” Aurum Mühendislik Sistemleri Ve Mimarlık Dergisi, Cilt 1, Sayı 2, 2017

[21] G. Daloğlu, "Eskişehir-Derbent Tüflerinin Doğal Yapı Tası Olarak Değerlendirilebilirliği”, Eskişehir Osmangazi Üniversitesi, Fen Bilimleri Enstitüsü, Yüksek Lisans Tezi, 2008

[22] O. Deniz, A. Baba, G. Tarcan, "Çan Jeotermal Alanı'nın Hidrojeokimyasal ve Hidrojeolojik İncelenmesi” Türkiye Jeoloji Bülteni Cilt 53, Sayı 2-3, 2010

[23] TS EN 1015-10, Birim Hacim Ağırlık

[24] TS EN 1015-18, Kapiler Su Emme

[25] TS EN 1015-11, Basınç Dayanım

[26] A. Özdemir, "Bazı Yapı Malzemelerinin Kapiler Su Emme Potansiyelleri" Jeoloji Mühendisliği, vol 26, no: 1,2002 